\title{
A FLANEUR IN TURIN. \\ THE PERCEPTION OF SPACE IN THE WORKS OF FRIEDRICH NIETZSCHE AND WALTER BENJAMIN
}

\section{A B S T R A C T}

This essay attempts to differentiate three different kinds of spatial-atmospheric experience on the basis of the theories by Hermann Schmitz and Robert Vischer. Furthermore, it connects these methods to the figure of the flaneur in Walter Benjamin's Passages as well as in the late Turin diaries of Friedrich Nietzsche. These two concepts of the flaneur can be seen as antithetic. For Walter Benjamin city strolling is a means of intellectual stimulation, focusing on impulses from the urban landscape that are then interwoven in associative, oscillating streams of thought, often commenting on the city stroller as an actor in a capitalist society. In contrast, Friedrich Nietzsches experience of architectural space can be seen as a full synthesis of inner life and outer experience, thought and motion intertwine, facilitating a new creative disposition and state of mind. 
INTRODUCTION

"Do you know Turin? [...] Calm, almost solemn. Classical ground for both feet and eyes. [...] A touch of the good eighteenth century. The kind of palaces that speak to our senses. [...] And that I can glimpse the snowy Alps from the centre of town! These long streets seem to lead straight towards their peaks. I would have never thought that light could make a city so beautiful."1

This enthusiastic and atmospherically dense description can be found in one of Friedrich Nietzsche's letters from Turin that he sends to his friend Carl Fuchs in 1888. In April of the same year he relocated from a little mountain village of Sils Maria in the Swiss Alpsto Turin, the capital of the Piemont. And, as mentioned above, he appearsto be delighted by his new home.

Since Nietzsche was formerly known as a philosopher of the mountains, a character of a rather melancholic, pensive nature prefering the tranquility of the natural landscape, it is legitimate to ask where this sudden change of mind comes from that turns him into an avid flaneur of the 'dignified and classical pavement ${ }^{2}$ of Turin.

If you look closer at Nietzsche's testimonials you will notice that he keeps using emotional states as well as personifications to describe the architecture of Turin. He talks about the 'honest and noble streets' and the 'dignified city' ${ }^{3}$. These emotions, the solemnity of the plazas, seem to merge with his own state of mind and stimulate his thoughts.

Based on these observations, this essay will address the question of how Nietzsche's perception, his experience of space as well as atmospheres, is articulated and how it influences his thinking and his philosophy. To further this analysis, the resulting term of the Philosophical Flaneur will be brought into consideration, looking both at its implementation in the works of Nietzsche and Benjamin.

\section{THE TERM OF ATMOSPHERE}

The term of atmosphere, as a means of perceiving space, shall be put in context here: Atmosphere derives from the Greek and is composed of atmós (meaning vapor or mist) and sphaira (meaning sphere or globe). 
This definition evokes a vivid image of a hazy globe or a fog that envelopes a landscape, creating a certain mood, which carries the anticipation of the atmosphere of a social or natural situation, before it is articulated. We can understand this phenomenon by looking at a beautiful landscape, its serene atmosphere leaving us immediately in a joyful mood. The geometrical element of the sphere already hints at the fact that the production and reception of an atmospherical mood is a cycle.

Hermann Schmitz defines atmospheres as "active and moving instances of feeling which press in (on the person perceiving an atmosphere) from outside." 4 Furthermore, they are "spatial carriers of emotional disposition."

The reception of atmospheres is here defined as an interaction, an aesthetical moment between two protagonists - man and space.

The one who is perceiving an atmosphere embodies the role of the receptor, because "perception means being affected" (by an atmosphere) and "being in coalescent participation" (in the atmospheric production). The receptor has by no means a passive role. Just as an atmosphere streams into space and occupies it, man streams into the world as well. The atmosphere of a space influences the emotional constitution.

The receptor, though, also charges the space with meaning by projecting his emotional condition onto the situation. The concept of atmosphere is a concept of the in-between: between objective conditions and subjective states, between object and subject.

So the question to be asked is: In which way are we influenced by the atmosphere of a certain space? How are we affected by differing architectural dramaturgies, places of atmospheric ambiance? In which way do certain atmospheres impact our emotional constitution and therefore our thinking? To tackle this question, I want to introduce three different forms of spatial-atmospheric experience:

THE SACRED SPACE

Affective and Immediate Agitation

Walking into St. Peter's Basilica or another building of similar figure, we can discover a certain scenario: The visitors are walking in awe-stricken silence, looking up to the ceiling, in full admiration of the spatial effect, some 
exclamations of wonder are heard. The visitors are deeply stirred and seemingly stunned by the spatial dramaturgy. Looking at the enormous ceiling height, the pompous interieur as well as the powerful direction of light, it is no wonder that the visitor is in complete awe, leaving him in a certain state of physical helplessness.

These observations suggest a comparison with the experience of the Sublime, which as defined by Immanuel Kant, is:

"After an initial reluctance provoked by physical helplessness, a sensation of lust follows, sparked by the finding of the superiority of our own power of reason which rises above the bodily inadequacies."

Thus, man is elated by overcoming his own physical insufficiency by virtue of imagination (Einbildungskraft). In Kant's writing, the experience of the Sublime has been closely related to objects inspiring awe because of the magnitude of their size (e.g. the ocean, the pyramids, the mountains), force (a storm), or transcendence (our idea of God), whereas Nietzsche sees it as a basic element of the spatial-atmospheric experience in ancient Greek architecture. ${ }^{8}$

The feeling of the Sublime is to be experienced on a physical as well as an emotional level. The reaction to the spatial-atmospheric dramaturgy of a basilica is immediate and affective.

Coming back to the question of how our thought process is affected: In such a situation of great atmospheric force leading to an intensive response of mind and body, it is unlikely to have clear thoughts, keeping a rational perspective. The beholder is affectively agitated and absorbed in the experience.

To further understand the experience of space in the works of Benjamin's The Arcades Project, as described in the following paragraphs, it is important to turn to the figure of the flaneur at first.

\section{THE FLANEUR}

The term „flaneur“ appeared for the first time in Edgar Allan Poe's Man in the Crowd in the literary realm, Baudelaire and Apollinare followed.

The flaneur embraces The Art of Taking a Walk. He is a wanderer without destination, outside a given timeframe. He immerses himself in the passing 
crowd, intoxicated by his own movement. His perception oscillates between detailed observation of things of relative irrelevance - like the colors of socks in a store display - and a meditative, almost absent-minded state of consciousness, close to an Inner Walk. His mind wanders, his steps become independent. The city blurs and becomes a screen for psychological projection.

WALTER BENJAMIN

Immersive, Unconscious Agitation

In the beginning of his chapter on the Flaneur, Benjamin cites Marcel Réja:

"Et je voyage pour connaître ma géographie.""

This quote already hints at the fact that flâner, to stroll, does not simply refer to taking a walk, but that there is more to it.

The setting of The Arcades Project is Paris, the capital of the nineteenth century, as Benjamin puts it. The increasing industrialisation, that causes the city to be lined by the tracks of the new means of transportation, buses and cable cars, encompasses a new feeling of acceleration.

Moreover, the building of a canal system (making it actually pleasant to walk the streets) offers a new way of urban life. The public space is born, the city becomes an extended living room, the street becomes the stage of the flaneur.

The building of the elegant Paris Arcades, with colorful window displays, shops and other opportunities for amusement, facilitates this development. People become pedestrians, crowds are occupying the streets, a hectical atmosphere and a density of visual stimulus becomes normality. These developments, an unprecedented accumulation of random human interaction foreshadowing the urban anonymity, an accumulation of consumer goods, presenting themselves in bold colours, street noise, in short: the acceleration of the living conditions holds the risk of mental overstimulation. Walter Benjamin locates his figure of the flaneur in this context:

"An intoxication comes over the man who walks long and aimlessly through the streets. With each step, the walk takes on greater momentum; ever weaker grow the temptations of shops, of bistros, of smiling women, ever more irresistible the magnetism of the next streetcorner, of a distant square in the fog, of the back of a woman walking before him. Then comes hunger. Our man wants nothing to do with the myriad 
possibilities offered to sate his appetite, but like an animal, he prowls through unknown districts in search of food, in search of a woman, until, utterly exhausted, he stumbles into his room, which receives him coldly and wears a strange air."

The flaneur is intoxicated by the city, seduced and fails at his own delusion. To cope with this overstimulation, the buzzing atmosphere of the city, which is reflected in his maniac way of walking, his mind wanders off and he falls into a state of Inner Reflection.

"The street conducts the flaneur into a vanished time. For him, every street is aslope. It leads downward- if not to the mythical Mothers, then into a past that can be all the more stunning because it is not his own, private past. Nevertheless, it always remains the time of a childhood. But why that of the life he has lived? In the asphalt over which he passes, his steps awaken a surprising resonance. The gaslight that streams down on the pavement throws an equivocal light on this double ground."11

Georg Simmel explains the typical airieness, the arrogance and indifference of the city dweller as a mechanism of coping with mental overstimulus. Benjamin takes up a different stance: "The city as a mnemonic for the lonely walker: it conjures up more than his childhood and youth, more than its own history."12

So, after Benjamin, city strolling becomes an intoxicant, and functions as a threshold to the subconcious. Nemonics can be translated as: The art of memory. It is used to organize memory impressions and assist in the creative combination and invention of ideas on the basis of memory. Within the meaning of nemonics, the experience of the buzzing haze of the city facilitates associative thinking.

Inspired by the aesthetics of chaos, man recalls for once fragments of his own biography, then associations and thoughts in the broader sense of the stream of consciousness.

\section{FRIEDRICH NIETZSCHE}

\section{Aesthetical Contemplation}

"Sit as little as possible. Have no faith in any thought that was not born outdoors while one moved about freely -in which the muscles are not celebrating a feast, too." 13 
Nietzsche gives this advice in his work Ecce Homo, which came to being during his stay in Turin in 1888-1889. Before relocating to Turin, he was widely known as the wandering philosopher, who virtually composed his philosophy while wandering in the solitude of the Swiss mountains. Now we can witness a transformation, as he is converting to an enthusiastic Flaneur with his arrival in Turin:

"This is a city I can use now! What a worthy and serious city! Not at all a metropolis, not at all modern, as I had feared: rather, it is a city of seventeenth-century royalty. What safety, what sidewalks. What solemn and earnest piazzas! And the palaces are built without pretension, the streets clean and well made - everything far more dignified than I expected! These arcades are necessary here, given the changeable weather: yet they are spacious, not at all oppressive. The most beautiful city I've ever seen." 14

He praises the "aristocratic tranquility" and the "noble and serious streets," 15 which seem to fuse with his own state of mind. Against the common perception of the romantic landscape of the Swiss Alps, one must not overlook how the loneliness in the harsh mountainous landscape affects the emotional state:

"The passion caused by the great and the sublime in nature, when those causes operate most powerfully, is shuddering in astonishment; and astonishment is that state of the soul in which all its motions are suspended, with some degree of horror."'16

The atmosphere of the sublime found in nature can inspire greatly, but also exposes to the danger of depression. Turin seems to provoke the opposite: The city enlivens and quickens him and, at the same time, facilitates quiet contemplation that encourages creative expression. ${ }^{17}$

But why is that? To approach this question, I want to look closer at the architecture and its atmospherical potential: Turin is a city of arcades, framing the city and reminding us of monasterial cloister halls, which find their secular expression here.

An arcade is defined as an archway, as a sequence of round arches, with equal distance, fostering a calm and steady pace. In a sacral context, the cloister is placed around a monastery garden. It is an architecture of retreat with space for concentration and turning inwards. 
Accordingly, the Arcades of Turin can be seen as an inversion of the sacral cloister hall. The archway as a space of contemplation is laid around the city like a belt. It acts as a space in-between, as a threshold between the person perceiving the space and the things that surround him. The architecture of the urban life is not shielded away, but in contrast to the perception of the flaneur in the works of Benjamin, perceived and experienced through a certain distance, a protecting filter.

The archway unfolds its spatial-atmospheric effect on the base of its architectural means: rhythm, repetition, light and shadow. The rythm of the columns with its recurrent intervals alleviate the mind, since the decoding of the space is simple.

In the fabric of the streets of an unknown part of the city it is necessary for the flaneur to adapt to everchanging spatial configurations (narrowness, width, the play of shapes). Body and mind have to actively get accustomed to the space and position themselves in the spatial field. The archway on the contrary, accompanies the flaneur silently, his pace follows the recurrent dimensions of the axis the archway, the shadow of the columns paints a regular pattern on the floor. The city bypasses the flaneur in comfortable distance, framed by the row of the columns, just like the sequence of paintings on a wall in an exhibition.

In contrast to the visual-atmospheric overstimulation of the flaneur in the works of Benjamin, here we encounter the image of the vita contemplativa. The arcade presents itself as an urban space of repose and contemplation. To understand the effect of the arcade in a more profound way, from a phenomenological perspective, I want to look into the work of Robert Vischer.

In his dissertation On the Optical Sense of Form: A Contribution to Aesthetics, he proposes a new distinction between to understand and feeling into (empathise) which later became to be known as the Einfühlungstheorie. ${ }^{18}$ Vischer describes Einfühlung (feeling into something or someone) as the immediate, feeling into the matter of the things by means of a shared spatial reality. Empathy, according to Vischer, animates the world of inert matter. Through both sensory and bodily observation, we feel not only the presence of the thing, but we feel our way into the objects of our attention. We step into a bodily interaction with an object and appropriate it with both our emotional and our corporal being. We project our own bodily form, and with this also the soul, into the form of the object.19 In this context, it is possible to interpret the following quote by Nietzsche in a new way: 
"We want to see ourselves translated into stones and plants, we want to take walks in ourselves as we stroll around these halls and gardens." ${ }^{20}$

It is imaginable how Nietzsche experiences his promenades in the Arcades of Turin: The sequence of the archways with their continous play of the shadow punctuates the space and accompanies him with its calming rhythm, which enlivens but also facilitates quiet contemplation.

Friedrich Theodor Vischer describes this as follows:

"The different dimensions of line and area, the differences in their movement act in an allegorial manner: The vertical elevates, the horizontal widens, the curved moves more lively than the straight. Following an inner necessity of the nature of our soul, we attribute a mental disposition to the abstract forms of appearance so that our own inner life appears to meet us in them." 21

So, the dynamic or static character of an architectural form can be experienced on a corporeal level and resonates in our emotions. Whenever Nietzsche describes Turin as a 'dignified, serious city' and speaks about the 'aristocratic tranquility', after the theory of Vischer, he rather describes his own state of mind in which the promenade in the arcades has transported him. Hermann Schmitz describes this state of mind, a serene, pleasurable aesthetic experience from a distance as Aesthetical Contemplation. ${ }^{22}$ In contrast to the thorough devotion - and therefore surrender - to the aesthetic experience, Aesthetical Contemplation defines an

"intense devotion, but with a certain distance in the state of astonishment, which is neither a thorough surrender to the aesthetical experience, nor a suppression of the emotional impact of the atmosphere."23

\section{CONCLUSION}

This form of aesthetical experience enables man to intensive emotions and moments of inspiration, without losing control and getting lost in the immersive power of the spatial atmosphere. Only this intermediate state, in-between thorough surrender and emotional self-assertion, enables man to implement the inspiration derived from the aesthetical pleasure in a productive manner, unfolding new creativity. 
Outside of this equilibrium, in the haze of the feeling, man is deprived of his scope of action, of being able to transform the creative impulse and becomes a passive consumer of beauty. Therefore, the premise of true aesthetic enjoyment within the meaning of Aesthetical Contemplation is distance in the presence of affective aesthetic forces.

The Arcades of Turin, these "magnificent porticoes and columned halls," ${ }^{24}$ are a true architectural discovery for Nietzsche and become a source of inspiration. It is here in Turin where he lays the foundation for his work Ecce Homo.

The quiet streets and solemn squares allowing for Aesthetical Contemplation finally provide for a place, where, after Nietzsche, "we godless can think our thoughts. ${ }^{25}$ in the Summer Semester of 2017 at TU Berlin and was further developed through the Summer School 'Between Intellectual and Sensory Reason: Towards an Epistemology of Architecture' in Dubrovnik, Croatia, with Prof. Jörg H. Gleiter, Prof. Petar Bojanic, Prof. Snježana Prijić Samaržija and others.

Friedrich Nietzsche, "Briefe Januar 1887 - Januar 1888, Bd. 8," in Sämtliche Briefe, Kritische Studienausgabe in 8 Bänden (München: De Gruyter, 1986), 293. phänomenologische Reduktion (Berlin: LIT, 2007), 293. 
Friedrich Nietzsche, Menschliches, Allzumenschliches, (Hamburg: Meiner, 2014), 164.

Walter Benjamin, "Das Passagenwerk," in Gesammelte Schriften, Bd. 5 (Frankfurt am Main: Suhrkamp Verlag, 1982), 24.

Walter Benjamin, "Kritiken und Rezensionen," in Gesammelte Schriften, Bd. 3 (Frankfurt am Main: Suhrkamp Verlag, 1986), 525.

Ibid., 524.

Ibid., 194.

Friedrich Nietzsche, Ecce Homo. Wie man wird, was man ist, (München: dtv Verlag, 2005), 25.

Friedrich Nietzsche, Sämtliche Briefe, Kritische Studienausgabe in 8 Bänden, (München: dtv Verlag, 2003), 296.

Ibid., 297.

Edmund Burke, Vom Erhabenen und Schönen, (Hamburg: Meiner, 1989), 91.

Friedrich Nietzsche, Die Fröhliche Wissenschaft. Wir Furchtlosen, (Hamburg: Meiner, 2014), 175.

Robert Vischer, "Über das Optische Formgefühl," in Drei Schriften zum ästhetischen Formgefühl, (Halle/Saale: Niemeyer, 1927), 10.

Ibid., 12.

Friedrich Nietzsche, Die Fröhliche Wissenschaft. Wir Furchtlosen, (Hamburg: Meiner, 2014), 176.

Hermann Schmitz. Der Leib, der Raum und die Gefühle, (Bielefeld: Aisthesis Verlag, 2015), 91.

Ibid., 92.

Ibid., 94.

Friedrich Nietzsche, Die Fröhliche Wissenschaft. Wir Furchtlosen, (Hamburg: Meiner, 2014), 175.

Ibid., 176. 
Benjamin, Walter. Das Passagenwerk. Frankfurt am Main: Suhrkamp Verlag, 1982.

Böhme, Gernot. Einfühlung und phänomenologische Reduktion. Berlin: LIT, 2007.

Burke, Edmund. Vom Erhabenen und Schönen. Hamburg: Meiner, 1989.

Grave, Johannes. Metzler Handbuch Kunstwissenschaft. Stuttgart: J.B. Metzler, 2011.

Nietzsche, Friedrich. Die Fröhliche Wissenschaft. Wir Furchtlosen. Hamburg: Meiner, 2014.

Nietzsche, Friedrich. Ecce Homo. Wie man wird, was man ist. München: dtv Verlag, 2005.

Nietzsche, Friedrich. Sämtliche Briefe, Kritische Studienausgabe in 8 Bänden. München: dtv Verlag, 2003.

Schmitz, Hermann. Der Leib, der Raum und die Gefühle. Bielefeld: Aisthesis Verlag, 2015.

Vischer, Robert. Drei Schriften zum ästhetischen Formgefühl. Halle/Saale: Niemeyer, 1927. 


\section{PROSTORI ZA PROMIŠLJANJE - GDE JE MESTO FILOZOFIJE? \\ Ludger Schwarte}

Ako rezonovanje podrazumeva određenu arhitekturu (koncepata), čin rezonovanja nije nezavisan od vrlo konkretnih arhitektonskih dispozicija. U svom radu ću, za početak, dati skicu mesta, koja su projektovana kao prostori za promišljanje, zatim dekonstruisati implicitne pretpostavke odnosa sa arhitekturom, i na kraju, pokušati da pokažem kako praksa filozofije zavisi od arhitektonske postavke.

KLJUČNE REČI: FILOZOFIJA, ARHITEKTURA, PROSTOR ZA PROMIŠLJANJE

ISTRAŽIVANJE IDEJA NAŠIH ČULA

ISTRAŽIVANJE KANTOVE SPOSOBNOSTI MAŠTE U UNGEROVIM

"METAFORAMA GRADA"

\section{Andrea Weigt}

Čula i ideje, kako se oni susreću? Povezanost sfere čula i čistog uma se nalazi u filozofiji Imanuela Kanta, posebno u njegovoj teoriji o ljudskoj sposobnosti maštanja. Ovaj tekst analizira njegove ideje u pogledu tog svojstva, a posebno koncepta slobodne igre. Kroz primere kreativnih procesa arhitekata, pokazaću kako slobodna igra između sposobnosti mašte i spoznaje menja našu percepciju. U tom stanju percepcije, ideje nastaju iz naših čulnih inputa. Osvald Ungers (Oswald M. Ungers) je dalje obrazložio da ideja daje život njegovim kreacijama u svojoj publikaciji "Metafore grada", koja je i glavna referenca ovog rada. Po njegovom tumačenju, "Metafore grada" mogu temeljno pokazati ovo izmenjeno stanje percepcije ukoliko je povezano sa Kantovim teorijama i njegovim shvatanjem mašte. "Metafore grada" mogu čak biti posmatrane i kao istraživanje mašte koje zadire u slobodnu igru. U svom zaključku ću koristiti projekte Le Korbizjea i Alvara Alta kako bih ilustrovala značaj mašte $u$ datim primerima projektantskog procesa.

KLJUČNE REČI: MAŠTA, PROJEKTOVANJE, KREATIVNOST, SLOBODNA IGRA, ŠEMA, TRANSCENDENTALNA

FILOZOFIJA, OSVALD UNGERS, IMANUEL KANT, KRITIKA RASUĐIVANJA

\section{FENOMENOLOŠKI NAČINI ZA PROMIŠLJANJE ARHITEKTURE}

\section{Carla Danani}

S osvrtom na dugu i antropološku tradiciju, koja je procvetala iz fenomenološke i hermeneutičke misli, predlažem razumevanje ljudskog bića kao "telesna savest" ili "otelovljenje savesti". Za razliku od predmeta, ljudska bića imaju vezu sa prostorom, koja je suštinska za njihovo postojanje. Moj cilj je da produbim značenje ovog "ljudskog bitisanja" s posebnim osvrtom na pitanja izgradnje i projektovanja. Mesta nisu samo kontekst, puke pozadine gde se događaji i aktivnosti odvijaju, već ona igraju aktivnu ulogu u izgradnji odnosa, grupa, mašte i samosvesti.

KLJUČNE REČI: PROJEKAT, MESTO, VREME, TELO, PAMĆENJE, MESTO STANOVANJA, SREDINA

\section{ŠETAČ (FLANEUR) U TORINU \\ PERCEPCIJA PROSTORA U RADOVIMA FRIDRIHA NICEA I VALTERA \\ BENJAMINA}

\section{Theresa Rauch}

Ovaj rad će pokušati da napravi razliku izmedju tri različite vrste prostorno-atmosferskog iskustva na osnovu teorija Hermana Šmitsa (Hermann Schmitz) i Roberta Višera (Robert Vischer). Osim toga, rad povezuje ove metode sa likom šetača (flaneur) u knjizi "Odlomci Valtera Benjamina" (Walter Benjamin's Passages) kao i dnevnicima o Torinu Fridriha Ničea (Friedrich Nietzsche). Ova dva koncepta flaneur-a se mogu posmatrati kao konfliktna. Za Benjamina je šetnja gradom sredstvo intelektualne stimulacije, sa fokusom na impulse iz urbanog pejzaža koji se zatim 
utkane u asocijativni, oscilirajući tok misli, često komentarušući urbanog šetača kao glumca u kapitalističkom društvu. Za razliku od toga, Niče smatra da doživljaj arhitektonskog prostora može biti sagledan kao sveobuhvatna sinteza unutrašnjeg života i spoljašnjeg iskustva, tj. preplitanje misli i pokreta, udomljujući (pomirujući) novu kreativnu dispoziciju sa stanjem svesti.

KLJUČNE REČI: FRIDRIH NIČE, VALTER BENJAMIN, FLANEUR, ATMOSFERA, URBANI PEJZAŽ, METROPOLA

\section{EPISTEMOLOŠKE IMPLIKACIJE NEUROARHITEKTURE}

\section{Hana Samaržija}

Ovaj rad će pokušati da objasni kako prostorne karakteristike izgrađenih okruženja utiču i na kognitivne procese proizvodnje znanja i epistemički kvalitet drugih logika ubeđenja. Skorije diskusije u filozofiji i društvenim naukama eksplicitno govore o promenjivoj dinamici savremenog života. Kako zamagljene granice između rada i slobodnog vremena primoravaju pojedince da utroše najveći deo svog vremena u izgrađenim okruženjima, lična iskustva prostora, objekata i enterijera postaju odlučujući faktor u samo-percepciji i spoznaji. Ove okolnosti su ohrabrile dolazak nove naučne oblasti: neuroarhitekture, ogranka funkcionalnog dizajna podržanog tehnologijom neurološkog skeniranja mozga i konceptom neuroplastičnosti, odnosno kapaciteta mozga da promeni svoju strukturu paralelno sa našim ponašanjem i okolinom. Ovaj rad nakon razmatranja ambicija neuroarhitekture da definiše najpoželjnije prostore po kriterijumu pozitivnih emocija, dobrog zdravlja, i intelektualne krepkosti, kritički će proceniti svoje epistemološke implikacije i njen potencijalno nepovoljan uticaj na arhitektonsku estetsku autonomiju. Ovaj upliv prirodnih nauka u prividno artistički domen arhitekture podseća nas na razlike između tradicionalnih analitičkih filozofija - koje su se bavile idealizovanim modelima intelektualnih i mentalnih procesa - i uvidom nauke u ljudske spoznaje, možda najbolje ilustrovana teorijom identiteta uma-mozga.

KLJUČNE REČI: NEUROARHITEKTURA, EPISTEMOLOGIJA, SPOZNAJA, UM-MOZAK IDENTITET, FILOZOFIJA UMA

\section{PREDSTAVLJANJE FRAGMENTARNOG U MODERNOJ ARHITEKTURI}

\section{Adria Daraban}

Pojam fragmentarnog u filozofskim i umetničkim diskursima obeležava početak moderne estetike i njihovo odvajanje od koncepta celine. Ovaj rad ilustruje moguća rezonantna polja oko pojma fragmentarnog u arhitekturi koji postavlja pitanja: Može li arhitektura biti oblik izražavanja savremenog stanja fragmentarnog? Da li se pojam fragmenta razvija u arhitekturi na sličan način kao i u oblastima vizuelne umetnosti, filozofije i književnosti, ili je fragment u arhitekturi sveden isključivo na oblik prezentovanja preseka? Može li se fragmentarno definisati kao pojam uslovljen vremenom i tako osloboditi od uobičajenog tumačenja pojma kao slike o isečku?

KLJUČNE REČI: FRAGMENT, HANS ŠARUN, AVANGARDNA ARHITEKTURA U NEMAČKOJ, NEMAČKI ROMANTIZAM, OGIST RODEN, FUTURIZAM

\section{KOLATERALNA LEPOTA: NICEOVA RAZMIŠLJANJA 0 ARHITEKTURI}

\section{Mirza Vranjaković}

Sa svojim tumačenjem apolonijskog i dionizijskog stanja u psihologiji, Niče (Nietzsche) je pokušavao da poveže eminentne dihotomije svoje ere - razum i instinkt, nauku i metafiziku, iskustvo i promišljanje, znanje i inspiraciju, pojavnost i celinu, red i haos. Kroz ovaj dualizam, on se kritički osvrće na celokupno nasledje zapadnjačke kulture. Predmetni rad analizira nekolicinu Ničeovih aforizama koji su direktno ili indirektno odnose na "umetnost izgradnje". Kroz aforizme, Niče je prizivao ideju nove arhitekture koja će se usprostaviti idealu zgrade devetnajstog veka: arhitektura ne idealizuje, ona nije samo pojava, već je izgrađena u duhu svog vremena, i navodi da se u nju uselimo, i na kraju, u arhitekturi lepota nije kraj već sredstvo za postizanje cilja. 